\title{
Water footprint calculation and assessment of viscose textile
}

DOI: 10.35530/IT.071.01.1642

JUXIANG ZHU

PINGHUA XU

YIDUO YANG

LAILI WANG

YI LI

\section{ABSTRACT - REZUMAT}

\section{Water footprint calculation and assessment of viscose textile}

Water footprint is used as an indicator to quantify the impacts on water resource and water environment. Based on water footprint standards established by the International Standardization Organization (ISO), this paper proposed a new quantitative indicator for water alkalization, and calculated the water footprints involved in viscose textile production. In addition, water footprint accounting results were comprehensively evaluated by LCA polygon method which was developed to interpret LCA results. Results showed that: (1) water scarcity footprint of viscose textile production was $60.511 \mathrm{~m}^{3} \mathrm{H}_{2} \mathrm{O}$ eq/ton, of which $85.71 \%$ was from the viscose fiber production; (2) water eutrophication footprint of viscose textile production was $12.439 \mathrm{~kg} \mathrm{PO}_{4}^{3-}$ eq/ton, the major contribution (84.37\%) was given by $C O D$ and $B O D_{5}$; (3) water acidification footprint and water alkaline footprint of viscose textile production were $81.453 \mathrm{~kg} \mathrm{SO}$, eq/ton and $55.675 \mathrm{~kg} \mathrm{OH}^{-}$eq/ton, mainly due to $\mathrm{H}_{2} \mathrm{SO}_{4}$ and $\mathrm{NaOH}$ input during the spinning process, respectively; (4) water ecotoxicity footprint of viscose textile production was $3828.169 \mathrm{~km}^{3} \mathrm{H}_{2} \mathrm{O}$ eq/ton, mainly derived from $\mathrm{Zn}^{2+}$ in spinning wastewater; (5) LCA polygon analyses showed that environmental load in the spinning was the largest, followed by the pulping and then the dyeing.

Keywords: viscose textile, water footprint, LCA polygon, calculation and assessment

\section{Calculul și evaluarea amprentei de apă a materialelor textile din viscoză}

Amprenta de apă este utilizată ca indicator pentru a cuantifica impactul asupra resurselor de apă și a mediului. Pe baza standardelor de amprentă de apă stabilite de Organizația Internațională de Standardizare (ISO), această lucrare a propus un nou indicator cantitativ pentru alcalinizarea apei și a calculat amprentele de apă implicate în producția materialelor textile din viscoză. În plus, rezultatele calculului amprentei de apă au fost evaluate prin metoda poligonului LCA, care a fost dezvoltată pentru a interpreta rezultatele LCA. Rezultatele au arătat că: (1) amprenta de apă a producției de materiale textile din viscoză a fost de $60,511 \mathrm{~m}^{3} \mathrm{H}_{2} \mathrm{O}$ ech./tonă, din care $85,71 \%$ proveneau din producția de fibre de viscoză; (2) amprenta de eutrofizare a apei din producția de materiale textile din viscoză a fost de $12,439 \mathrm{~kg}$ $\mathrm{PO}_{4}^{3-}$ ech./tonă, contribuția majoră $(84,37 \%)$ a fost dată de $C O D$ și $B O D_{5}$; (3) amprenta de acidifiere a apei și amprenta alcalină a apei din producția de materiale textile din viscoză au fost de $81,453 \mathrm{~kg} \mathrm{SO} \mathrm{S}_{2}$ ech./tonă și $55,675 \mathrm{~kg}$ $\mathrm{OH}^{-}$ech./tonă, în principal datorită aportului de $\mathrm{H}_{2} \mathrm{SO}_{4}$ și respectiv $\mathrm{NaOH}$ în timpul procesului de filare; (4) amprenta de ecotoxicitate a apei din producția de materiale textile din viscoză a fost de $3828,169 \mathrm{~km}^{3} \mathrm{H}_{2} \mathrm{O}$ ech./tonă, provenită în principal din $\mathrm{Zn}^{2+}$ din apele uzate; (5) analizele prin metoda poligonului LCA au arătat că filarea a înregistrat un impact semnificativ asupra mediului, urmată de procesare și apoi de vopsire.

Cuvinte-cheie: materiale textile din viscoză, amprentă de apă, metoda poligonului LCA, calcul și evaluare

\section{INTRODUCTION}

Water issues are common and about $32 \%$ of the water in China faces serious water pollution problems [1-2]. The textile industry is recognized as a precious stone for domestic economic in China [3] and viscose textile are favored by consumers because of their high clothing comfort, skin friendly nature and breathing capability [4]. China is the world's largest consumer of viscose staple fiber, and the apparent consumption of domestic viscose staple fiber increased from 1.49 million tons in 2011 to 3.49 million tons in 2017. Viscose fiber is made from raw materials such as cotton linters, wood or bagasse, which is alkali-impregnated to form alkali cellulose, reacted with carbon disulfide to form sodium cellulose sulfonate, and made into a spinning solution in a dilute alkali solution. The regenerated fiber is formed in the plasticizing bath, refined by drawing and cutting, and finally dried and packaged into a finished product. Then, it is spun and woven into a grey fabric, which is then dyed and finished into textile product. As can be seen from the above, viscose textile production process chain is long and complicated, and massive amount of water is consumed. According to statistics, the production of 1 ton of cotton pulp consumes 72 tons of freshwater, the production of 1 ton of viscose staple fiber consumes 65 tons of freshwater, and production of 1 ton of dyed textiles consumes 
100-120 tons of freshwater. Furthermore, the wastewater discharged into the environment is also in large quantities, which contains a large amount of alkali, organic matter, acidic pollutants and toxic pollutants, leading to multiple water environmental impacts. Water footprint based on the theory of virtual water was proposed by Hoekstra in 2002. Water Footprint Net (WFN) defined it as a volume measure of water consumption and water pollution both directly and indirectly by producers or consumers, including green water footprint, blue water footprint, and grey water footprint [5-7]. The water footprint developed by WFN focused the assessment of water sustainability and failed to reflect the environmental impact of water consumption and water pollution. Wang et al. introduced the water footprint methodology of the textile industry and applied it to the water footprint calculation of a dyeing factory [8]. In 2014, the ISO 14046 defined water footprint as a metric to quantify the potential environmental impacts, including water availability, scarcity, eutrophication, acidification, and ecotoxicity [9-10]. Water scarcity footprint is an indicator for measuring the impact of water use on local water resources, which has been applied to evaluate the water use in poultry, cables, cacao, dairy products and textiles [10-16]. Water degradation footprint is an indicator for quantifying the environmental impact of wastewater pollutants, which can be divided into water eutrophication footprint, water acidification footprint, and water ecotoxicity footprint according to the environmental impact category. These quantitative results are characterized by $\mathrm{PO}_{4}^{3-}$ (or $\mathrm{P}$ ) equivalent, $\mathrm{SO}_{2}$ equivalent and effluent equivalent, respectively [17-18]. Huang et al. and Bai et al. calculated water eutrophication footprint of crops and poultry, respectively $[10,19]$; Linhares et al. expressed the results of water eutrophication footprint and water ecotoxicity footprint in terms of $P$ equivalent and 1,4-DB equivalent, respectively [20]. These multidimensional indicators based on LCA (Life Cycle Assessment) theory can quantify the impacts of pollutants on the water environment from different angles, but makes it impossible to overview the water environmental load of different textile products or different process segments. To this end, "LCA polygon" methodology was developed to interpret LCA results. Daniel et al. considered LCA polygon as a tool for comparing the results of inventory analysis and Georgakellos et al. applied it to wastewater management and comparison of three soft-drink containers [21-23]. Lovarelli et al. based on the concept of similar LCA polygons, defined the polygon area based on the actual value of the quantitative index as the Water Pollution Water Indicator (PWI), and the larger the value of PWI, the more serious the degree of water pollution [24]. Therefore, it is possible to use a single indicator value as a general estimate of the combined output of each type of environmental impact, which facilitates a clear and objective comparison between different products or processes and helps to gain manageability.

The aim of this study was to quantify the impact of viscose textiles from cotton linters to dyed fabrics on water resources and water environment based on water footprint theory. According to the quantitative results, the LCA polygon method was used to comprehensively evaluate the water resources environmental load of production stages.

\section{MATERIALS AND METHODS}

\section{System boundary}

In this study, viscose textile went through three stages from raw material to fabric: viscose fiber manufacturing, weaving, fabric dyeing and finishing. Among them, viscose fiber manufacturing and fabric dyeing and finishing consumed a large amount of water resources, and the wastewater discharge caused multiple water environmental impacts (figure 1) [25-27].

\section{Water footprint}

\section{Water scarcity footprint}

Water scarcity footprint is used to assess the potential environmental impact associated with water scarcity in a region caused by production. The water stress index (WSI) was used as water scarcity characteristic

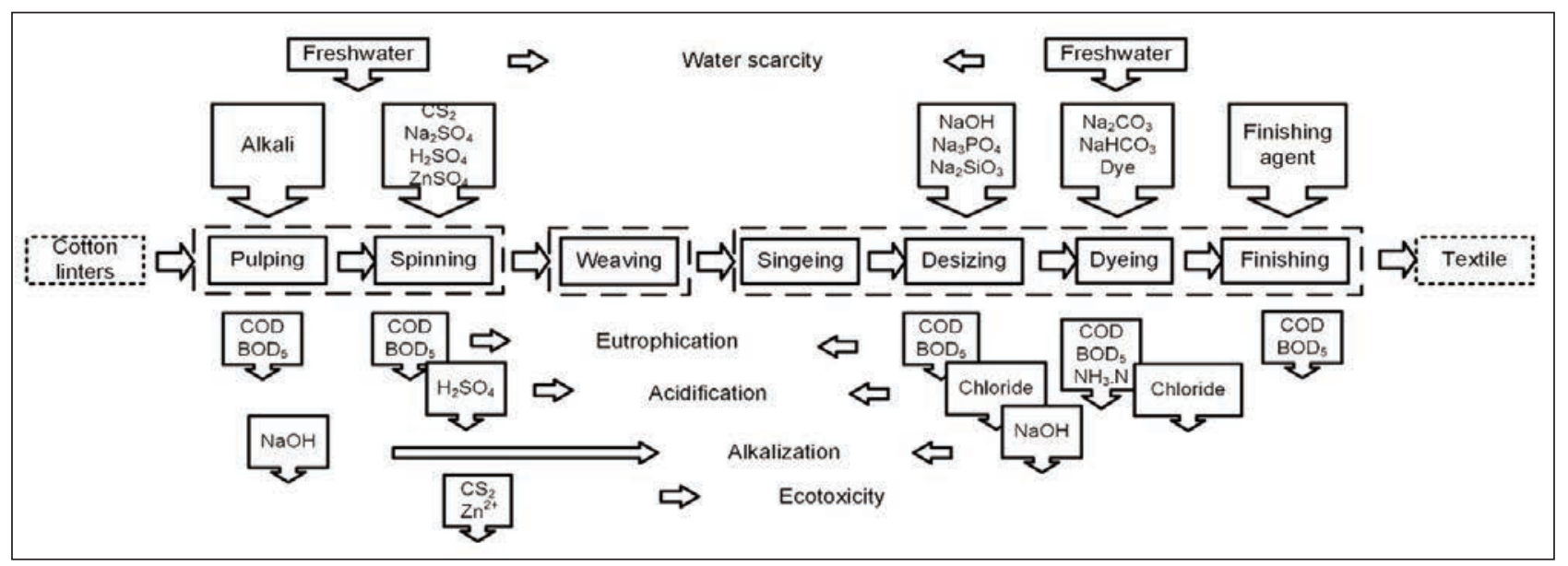

Fig. 1. System boundary of viscose textile production 
factor in this study, which was based on with-drawalto-availability ratio [28]. The calculation equation used for water scarcity footprint is as follows:

$$
W F_{s c}=\sum_{j}^{n} \frac{W S I_{j}}{W S I_{a v}} \times Q_{j}
$$

where $W F_{s c}\left(m^{3} \mathrm{H}_{2} \mathrm{O}\right.$ eq $)$ is water scarcity footprint; $Q_{j}$ $\left(\mathrm{m}^{3}\right)$ is freshwater consumption of per unit product in position $j ; W S I_{a v}$ is average water stress index of the global; $W S I_{j}$ is water stress index corresponding to $Q_{j}$.

\section{Water degradation footprint}

Water degradation footprint is used to measure the effects of pollutants on the water environment, which has included water eutrophication footprint, water acidification footprint, and water ecotoxicity footprint. Water eutrophication footprint is used to measure the potential water eutrophication impacts resulting from discharge of nitrogen and phosphorus pollutants. Water acidification footprint can be determined by pollutant emissions and the potentials that pollutants release hydrogen ion $\left(\mathrm{H}^{+}\right)$(as compared to sulfur dioxide $\left(\mathrm{SO}_{2}\right)$ ). Water ecotoxicity footprint is used to evaluate the toxic effect on species in the aquatic ecosystem, which is based on maximum tolerable concentration [17, 29]. The calculation methods of water eutrophication footprint, water acidification footprint, and water ecotoxicity footprint are as follows:

$$
\begin{aligned}
& W F_{E}=\sum_{i}^{n} C F_{E, i} \times M_{i} \\
& W F_{A C}=\sum_{i}^{n} C F_{A C, i} \times M_{i} \\
& W F_{A E T}=\sum_{i}^{n} C F_{A E T, i} \times M_{i}
\end{aligned}
$$

where $W F_{E}(\mathrm{~kg}), W F_{A C}(\mathrm{~kg})$ and $W F_{A E T}(\mathrm{~kg})$ are water eutrophication footprint, water acidification footprint and water ecotoxicity footprint, respectively; $C F_{E, i}$ $(\mathrm{kg} / \mathrm{kg})$ is characteristic factor of eutrophication pollutant $i ; C F_{A C, i}(\mathrm{~kg} / \mathrm{kg})$ is characteristic factor of acidification pollutant $i ; C F_{A E T, i}\left(\mathrm{~m}^{3} / \mathrm{mg}\right)$ is characteristic factor of ecotoxic pollutant $i ; M_{i}(\mathrm{~kg})$ is the emission of pollutant $i$.

Existing water degradation footprint indicators lack quantitation methods for alkaline impact. This paper proposed water alkaline footprint to quantify the effects of water alkalinity caused by textiles produc- tion. Water alkaline potential can be considered as the propensity that pollutants accept $\mathrm{H}^{+}$(as compared to Hydroxide ion $\left(\mathrm{OH}^{-}\right)$). Water alkaline footprint is the alkaline potential of $1 \mathrm{~kg}$ of pollutant multiplying by the pollutant emissions. The calculation equation used for water alkaline footprint is as follows:

$$
W F_{A L}=\sum_{i}^{n} C F_{A L, i} \times M_{i}
$$

where $W F_{A L}(\mathrm{~kg})$ is water alkaline footprint; $C F_{A L, i}$ $(\mathrm{kg} / \mathrm{kg})$ is characteristic factor of alkaline pollutant $i$; $M_{i}(\mathrm{~kg})$ is the emission of pollutant $i$.

\section{LCA polygon}

In the hypothetical system of $n$ impact categories, regular $n$-sided polygons are formed, different axes represent environmental impact categories with different personality characteristics (proportions and units). The axes intersection is zero and different impact categories have different actual values, forming a new n-sided polygon called LCA polygon. In the radial system of the shaft, the order of the various water footprints affects the area of the polygon, so all possible multilateral areas should be calculated and averaged to make the results more objective. The number of triangles with $R_{i}$ and $R_{i+1}$ as sides is $n(n-1) / 2$, and the average area of the LCA polygon is calculated as Equation (6) [21]. Consequently, the area of the LCA polygon can be used to represent the combined value of water footprints, and the larger the area value, the more serious the environmental load.

$$
E_{a v}^{p o l}=n E_{a v}^{t r}=\frac{1}{2} \sin \left(\frac{360^{\circ}}{n}\right)\left\{n\left[\frac{2 \sum_{i, j=1, i<j}^{n} R_{i} R_{j}}{n(n-1)}\right]\right\}
$$

\section{Data}

Data of freshwater use, wastewater and pollutants discharge were collected based on the monitoring data of wastewater discharge ports of viscose fiber production enterprises and dyeing enterprises, which were derived from the website www.ipe.org.cn. The functional units were 1 ton of viscose fiber and 1 ton of fabric, respectively (table 1 and table 2 ). The envi-

\begin{tabular}{|c|c|c|c|c|c|c|c|c|c|}
\hline \multicolumn{2}{|c|}{$\begin{array}{l}\text { Production } \\
\text { stage }\end{array}$} & $\begin{array}{c}\text { Freshwater } \\
\left(\mathrm{m}^{3} / \mathrm{t}\right)\end{array}$ & $\begin{array}{c}\text { Wastewater } \\
\left(\mathrm{m}^{3} / \mathrm{t}\right)\end{array}$ & $\begin{array}{c}\text { COD } \\
\text { (mg/L) }\end{array}$ & $\begin{array}{l}\mathrm{BOD}_{5} \\
\text { (mg/L) }\end{array}$ & $\begin{array}{l}\mathrm{H}_{2} \mathrm{SO}_{4} \\
(\mathrm{mg} / \mathrm{L})\end{array}$ & $\begin{array}{l}\mathrm{NaOH} \\
\text { ( } \mathrm{mg} / \mathrm{L})\end{array}$ & $\begin{array}{c}\mathrm{CS}_{2} \\
(\mathrm{mg} / \mathrm{L})\end{array}$ & $\begin{array}{c}\mathrm{Zn}^{2+} \\
(\mathrm{mg} / \mathrm{L})\end{array}$ \\
\hline \multirow{2}{*}{ 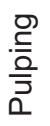 } & Presoaking & 40 & 36.76 & 8027 & 350 & - & 2400 & - & - \\
\hline & Washing & 25 & 23.95 & 585 & 200 & - & 200 & - & - \\
\hline \multirow{4}{*}{ 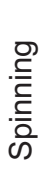 } & Stock solution & 4 & 3.48 & 2300 & 550 & - & 450 & 126.50 & 55 \\
\hline & Two-bath & 4 & 3.81 & 1037 & 200 & 12000 & - & 25.40 & 338 \\
\hline & Acid station & 16 & 14.42 & 415 & 100 & 790 & - & 25.84 & 28.73 \\
\hline & Scouring & 28 & 25.42 & 868 & 150 & 2480 & - & 17.47 & 298 \\
\hline
\end{tabular}
ronmental impact characteristic factors involved in this paper are shown in table $3[17,30]$. The WSI of China was 0.478 [10] and the average WSI of the global was 0.602 [31].

Table 1 


\begin{tabular}{|c|c|c|c|c|c|c|c|c|}
\hline \multicolumn{9}{|c|}{ FRESHWATER USE, WASTEWATER AND POLLUTANTS DISCHARGE OF FABRIC DYEING AND FINISHING } \\
\hline $\begin{array}{l}\text { Production } \\
\text { stage }\end{array}$ & $\begin{array}{c}\text { Freshwater } \\
\left(\mathrm{m}^{3} / \mathrm{t}\right)\end{array}$ & $\begin{array}{c}\text { Wastewater } \\
\left(\mathrm{m}^{3} / \mathrm{t}\right)\end{array}$ & $\begin{array}{c}\text { COD } \\
\text { (mg/L) }\end{array}$ & $\begin{array}{l}\mathrm{BOD}_{5} \\
\text { (mg/L) }\end{array}$ & $\begin{array}{l}\mathrm{NH}_{3} \mathrm{~N} \\
\text { (mg/L) }\end{array}$ & $\begin{array}{l}\text { Chloride } \\
\text { (mg/L) }\end{array}$ & $\begin{array}{l}\mathrm{NaOH} \\
(\mathrm{mg} / \mathrm{L})\end{array}$ & $\begin{array}{c}\mathrm{Na}_{2} \mathrm{CO}_{3} \\
(\mathrm{mg} / \mathrm{L})\end{array}$ \\
\hline Desizing & 4.50 & 4.48 & 5000 & 1000 & 15 & 100 & 2500 & 100 \\
\hline Dyeing & 13.50 & 13.45 & 800 & 200 & 2.50 & 250 & 1800 & 66 \\
\hline Finishing & 1.50 & 1.50 & 250 & 300 & - & - & - & - \\
\hline
\end{tabular}

Table 3

\begin{tabular}{|c|c|c|c|}
\hline \multicolumn{4}{|c|}{$\begin{array}{c}\text { ENVIRONMENTAL IMPACT CHARACTERISTIC } \\
\text { FACTORS }\end{array}$} \\
\hline $\begin{array}{c}\text { Environmental } \\
\text { impact }\end{array}$ & Pollutant & $\begin{array}{c}\text { Characteristic } \\
\text { factor }\end{array}$ & Unit \\
\hline \multirow{3}{*}{ Eutrophication } & COD & 0.022 & \multirow{3}{*}{$\mathrm{kg} / \mathrm{kg}$} \\
\hline & $\mathrm{BOD}_{5}$ & 0.11 & \\
\hline & $\mathrm{NH}_{3} \mathrm{~N}$ & 3.64 & \\
\hline \multirow{2}{*}{ Acidification } & $\mathrm{H}_{2} \mathrm{SO}_{4}$ & 0.65 & \multirow{2}{*}{$\mathrm{kg} / \mathrm{kg}$} \\
\hline & Chloride & 0.88 & \\
\hline \multirow{2}{*}{ Alkalization } & $\mathrm{NaOH}$ & 0.425 & \multirow{2}{*}{$\mathrm{kg} / \mathrm{kg}$} \\
\hline & $\mathrm{Na}_{2} \mathrm{CO}_{3}$ & 0.321 & \\
\hline \multirow{2}{*}{ Ecotoxicity } & $\mathrm{Zn}^{2+}$ & 0.38 & \multirow{2}{*}{$\mathrm{m}^{3} / \mathrm{mg}$} \\
\hline & $\mathrm{CS}_{2}$ & 0.18 & \\
\hline
\end{tabular}

\section{RESULTS AND DISCUSSIONS}

\section{The water footprints of viscose textile}

Figure 2 shows the water scarcity footprint of viscose textile production. From figure 2, we can see that water scarcity footprint of viscose textile production was $60.511 \mathrm{~m}^{3} \mathrm{H}_{2} \mathrm{O}$ eq/ton, and was divided into two parts: viscose fiber manufacturing and fabric dyeing

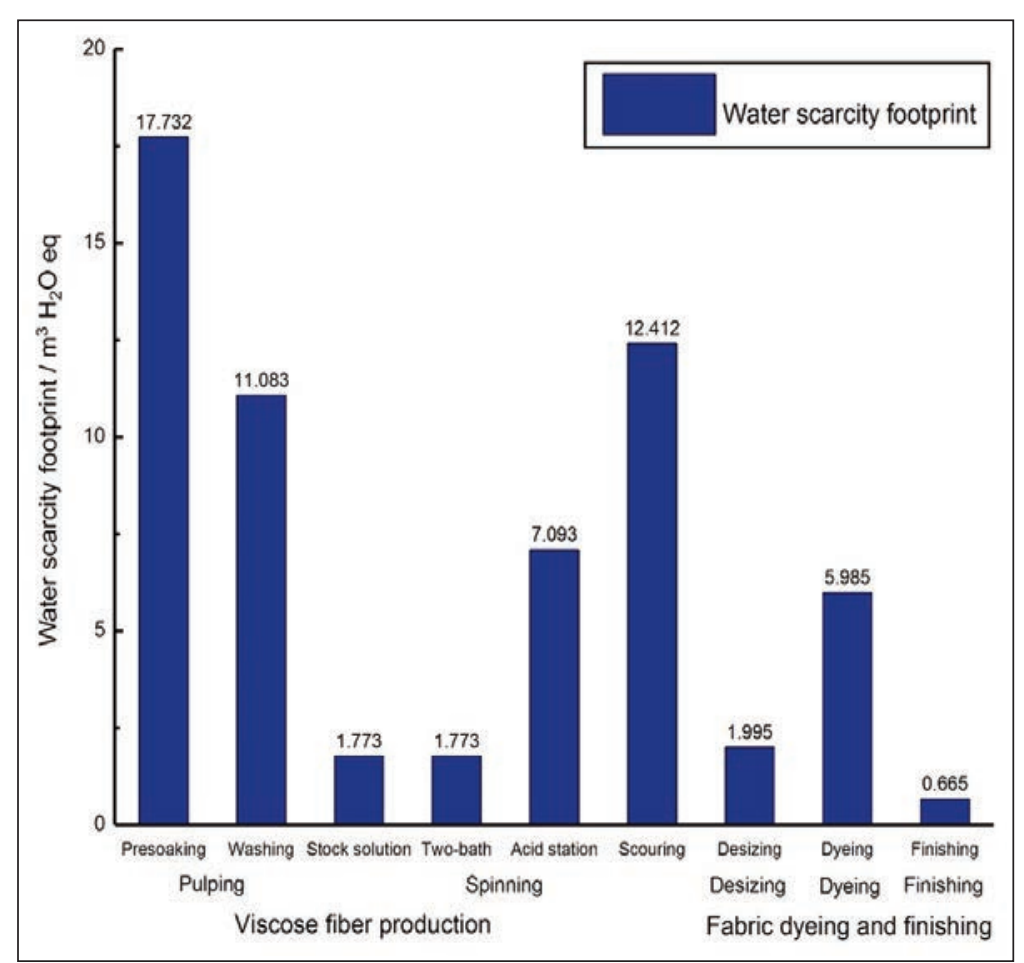

Fig. 2. Water scarcity footprint of viscose textile production and finishing, the water scarcity footprint of the former was generally larger than the latter. Water scarcity footprint of viscose fiber production was $51.866 \mathrm{~m}^{3}$ $\mathrm{H}_{2} \mathrm{O}$ eq/ton. Among viscose fiber production, the pulping process had the largest water scarcity footprint $\left(28.815 \mathrm{~m}^{3} \mathrm{H}_{2} \mathrm{O}\right.$ eq/ton) that was mainly from freshwater input in presoaking and washing processes and accounted for $55.6 \%$ of viscose fiber manufacturing stage. Water scarcity footprint of fabric dyeing and finishing was $8.645 \mathrm{~m}^{3} \mathrm{H}_{2} \mathrm{O}$ eq/ton. Among fabric dyeing and finishing, the dyeing process had the largest water scarcity footprint $\left(5.985 \mathrm{~m}^{3} \mathrm{H}_{2} \mathrm{O}\right.$ $\mathrm{eq} / \mathrm{ton})$, because the water use in the dyeing process included not only the dye liquor, but also the rinsing water after the dyeing.

Figure 3 , a shows the water degradation footprint results of viscose fiber production. From figure $3, a$, we can see that there were obvious differences between the pulping and the spinning. Water eutrophication footprint and water alkaline footprint of the pulping were $8.742 \mathrm{~kg} \mathrm{PO}_{4}^{3-}$ eq/ton and $39.531 \mathrm{~kg}$ $\mathrm{OH}^{-}$eq/ton, and were about 5.0 and 59.4 times as much as the spinning, respectively. The main raw material for the pulping process was cotton linters, which were immersed in lye, resulting in a large amount of organic and lye residues in the wastewater. Consequently, high concentrations of $\mathrm{COD}, \mathrm{BOD}_{5}$ and $\mathrm{NaOH}$ caused large water eutrophication footprint and water alkaline footprint, respectively. The pulping process did not cause water acidification footprint and water ecotoxicity footprint, while the water acidification footprint and water ecotoxicity footprints of the spinning process were $78.1 \mathrm{~kg} \mathrm{SO} \mathrm{g}_{2}$ eq/ton and 3828.206 $\mathrm{km}^{3} \mathrm{H}_{2} \mathrm{O}$ eq/ton, respectively. Water ecotoxicity footprint of the spinning process was caused by $\mathrm{CS}_{2}$ and $\mathrm{Zn}^{2+}$, which were from $\mathrm{CS}_{2}$ input in the stock solution and $\mathrm{ZnSO}_{4}$ input in the acid station, respectively. Water ecotoxicity footprint that $\mathrm{Zn}^{2+}$ contributed was $3598.078 \mathrm{~km}^{3}$ $\mathrm{H}_{2} \mathrm{O}$ eq/ton and accounted for about $94.0 \%$ of the total water ecotoxicity footprint. Water acidification footprint of the spinning process was mainly from $\mathrm{H}_{2} \mathrm{SO}_{4}$ input in acid station. This shows that the environmental impacts caused by wastewater discharge from different 
processes were different, which was mainly due to the different inputs of chemicals in different production processes. The concentration of $\mathrm{H}_{2} \mathrm{SO}_{4}$ in the two-bath wastewater was about 4.8 times that in the scouring wastewater, but the volume of the scouring wastewater was about 6.7 times that of the two-bath wastewater, consequently the water acidification footprint of the scouring was the largest, the value was $40.977 \mathrm{~kg} \mathrm{SO}$ eq/ton and contributed about $52.5 \%$ of water acidification footprint of the spinning process. Therefore, when assessing whether the wastewater quality meets emission standards, not only the concentration of pollutants should be detected, but also the corresponding amount of wastewater discharged.

Figure $3, b$ shows the water degradation footprint results of viscose fiber fabric dyeing and finishing stage. From figure $3, b$, we can see that water eutrophication footprint, water acidification footprint and water alkaline footprint were $1.944 \mathrm{~kg} \mathrm{PO}_{4}^{3-}$ eq/ton, $3.353 \mathrm{~kg} \mathrm{SO}$ eq/ton and $15.478 \mathrm{~kg} \mathrm{OH}^{-}$eq/ton, respectively. Water eutrophication footprint was mainly caused by $\mathrm{COD}, \mathrm{BOD}_{5}$ and $\mathrm{NH}_{3}^{-} \mathrm{N}$, where COD and $\mathrm{BOD}_{5}$ contributed about $78.5 \%$. Water acidification footprint came from chloride in the desizing and dyeing wastewater. Water alkaline footprint was caused by $\mathrm{NaOH}$ and $\mathrm{Na}_{2} \mathrm{CO}_{3}$, of which $\mathrm{NaOH}$ contributed about $97.6 \%$.

\section{Comprehensive evaluation}

\section{of the water footprints of viscose textile}

In this paper, LCA polygon method was applied to comprehensively evaluate the water footprints of viscose textile production. Firstly, the water footprint LCA polygons of viscose fiber production and fabric dyeing and finishing were drawn (figure 4) according to the water footprint accounting results of viscose textile production (figure 2 and figure 3 ).

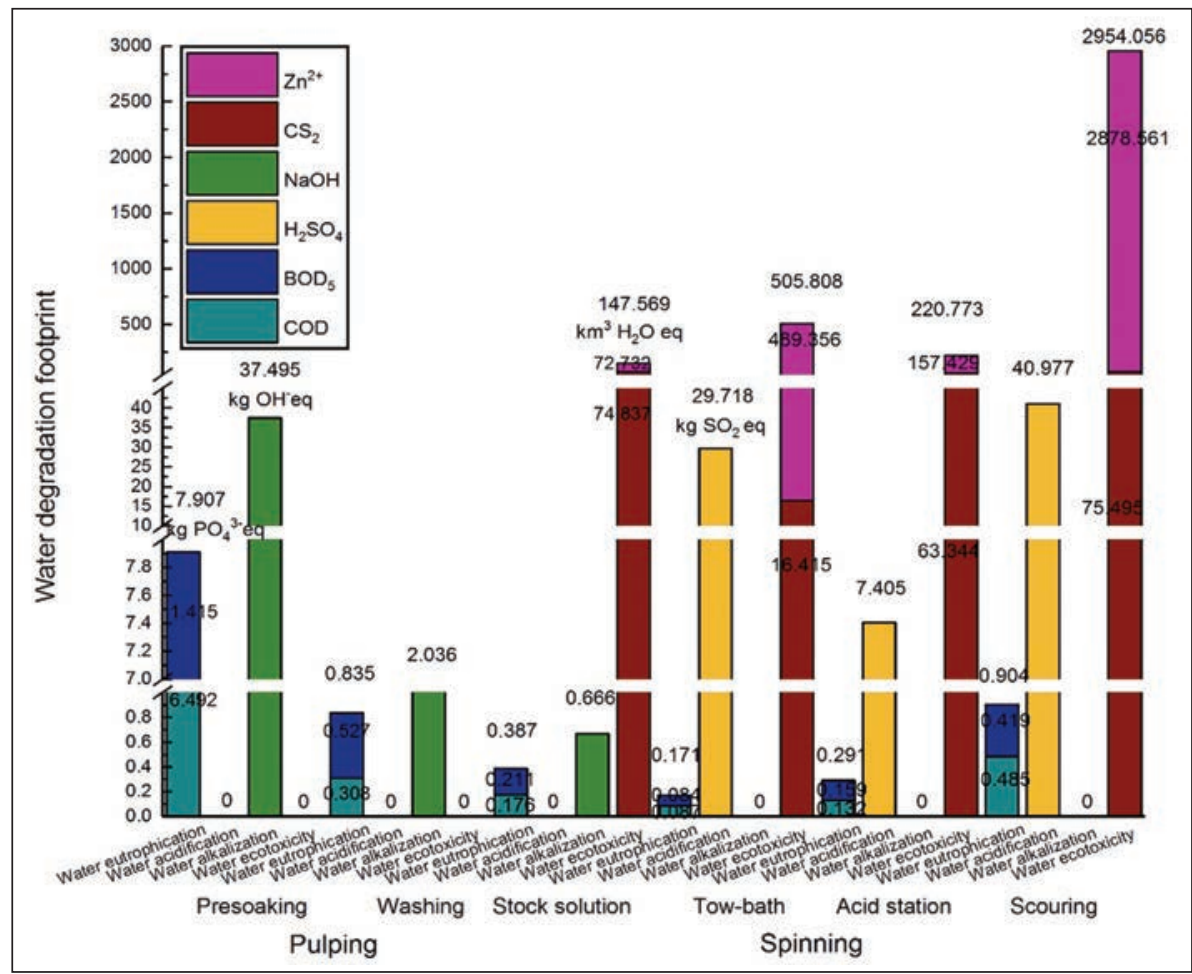

a

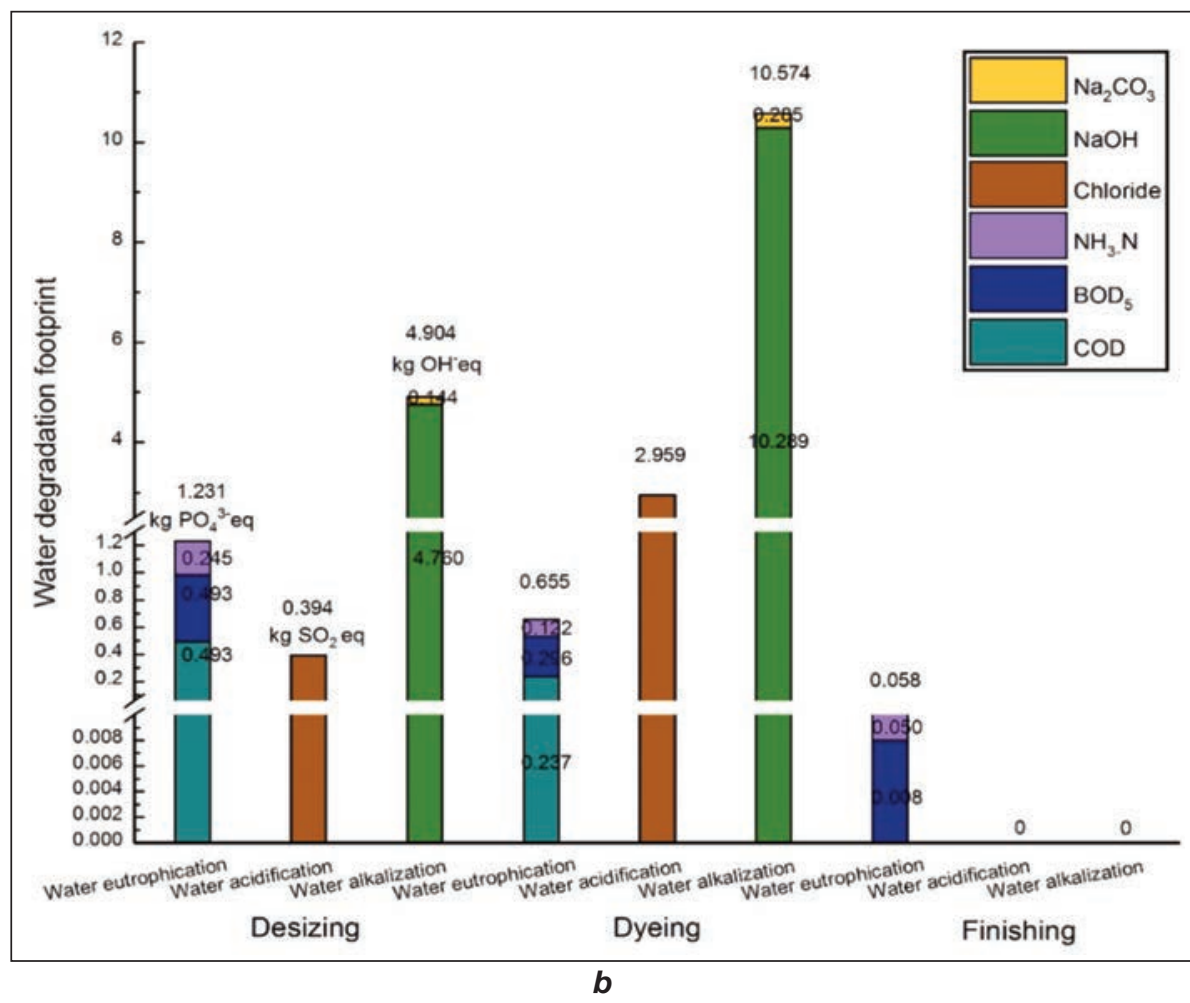

Fig. 3. Water degradation footprint of viscose textile: a - water degradation footprint of viscose fiber manufacturing stage; $b$ - water degradation footprint of viscose fiber fabric dyeing and finishing stage
Then, the areas of LCA polygon were calculated according to Equation (6). From figure 5, we can see that the water resources environmental load of the viscose fiber production was far greater than that of the fabric dyeing and finishing. The water resources environmental load of the scouring in the viscose fiber production was the largest, followed by the two-bath, the acid station and the stock solution, and 


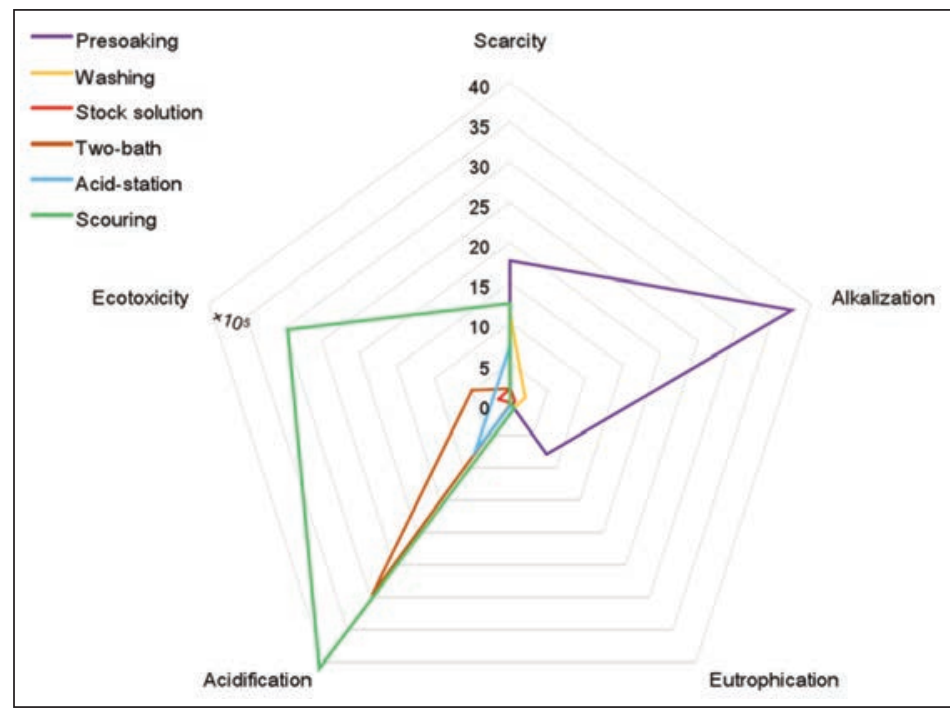

a

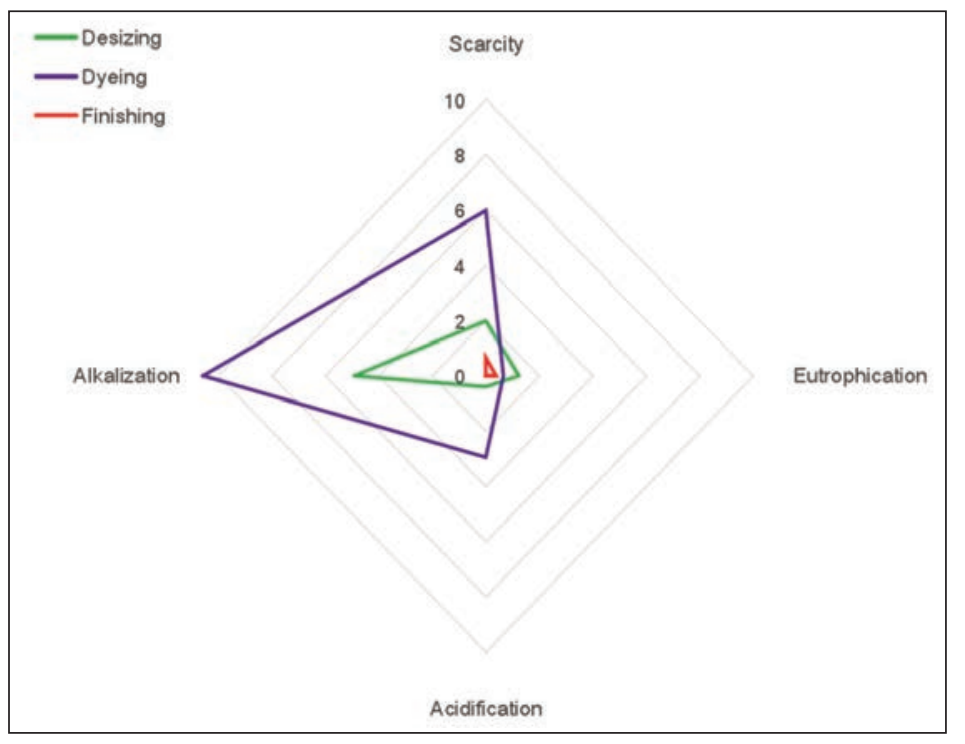

b

Fig. 4. Water footprint LCA polygon of viscose textile: $a$ - water footprint LCA polygon of viscose fiber manufacturing stage; $b$ - water footprint LCA polygon of viscose fiber fabric dyeing and finishing stage

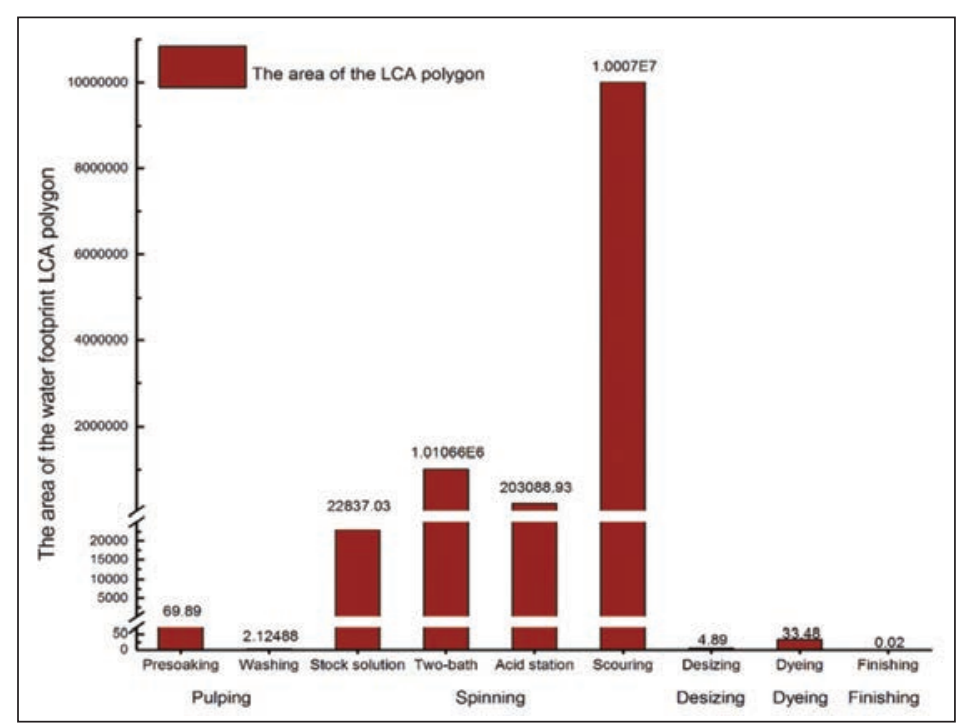

Fig. 5. The area of the water footprint LCA polygon of each production process then the presoaking and the washing. The areas of corresponding water footprint LCA polygon were 10006962.44, 1010657.30, 203088.93, 22837.03, 69.89 and 2.12, respectively. Combined with figure 2 and figure 3 , we found that water scarcity footprint, water eutrophication footprint and water alkaline footprint of the presoaking were larger than other five processes, but its LCA polygon area ranked fifth. This was because the presoaking did not cause water ecotoxicity footprint, but the four processes in front of it did. The fabric dyeing process caused four types of environmental impacts: water scarcity footprint, water eutrophication footprint, water acidification footprint and water alkaline footprint, but its comprehensive environmental impact score was less than the presoaking process involving only three types of environmental impacts, because its four indicator actual values were relatively small.

In summary, water resource environmental load of the viscose fiber production was larger than that of the fabric dyeing and finishing. Because the viscose fiber production involved the water ecotoxicity footprint and the actual value was very large, while the fabric dyeing and finishing did not involve. In this case, whether water ecotoxicity footprint could be considered as the dominant factor that causing the serious environmental load of the viscose fiber production.

\section{CONCLUSIONS}

Previous studies on the treatment of industrial production wastewater were mostly limited to the measurement and treatment of conventional pollutants such as COD and $\mathrm{BOD}_{5}$ [32-34]. For the first time, this paper comprehensively analysed the environmental impact of wastewater pollutants according to the characteristics of input and output of viscose fiber textile production process. Based on the ISO 14046 method, the environmental impacts of pollutant were classified and quantified, the water alkaline footprint was proposed and the accounting model was constructed to make up for the lack of water alkaline quantification methods in the ISO method.

This study performed water footprint and LCA polygon analyses of viscose textile production and explored the key factors that contribute to environmental load on water resource. The water footprint analyses showed that water resources environmental load caused by viscose textile production was mainly derived from water scarcity, water eutrophication, water acidification, 
water ecotoxicity and water alkaline. In wastewater treatment, it is often only concerned with high concentrations of conventional contaminants. But in this study, it can be seen from the water environmental load LCA polygon and its area value that the water ecotoxicity footprint that $\mathrm{Zn}^{2+}$ and $\mathrm{CS}_{2}$ caused contributed more to the comprehensive assessment results of water resources environmental load, although their contents were lower than other pollutants. In addition, in general research, $\mathrm{CS}_{2}$ is generally considered to be a gas and only causes air pollution. However, a small portion of $\mathrm{CS}_{2}$ in this study was dissolved in acid station and discharged with the wastewater, resulting in water ecotoxicity. Therefore, in order to reduce the water ecotoxicity footprint of the viscose fiber production, the relevant production department can appropriately adjust the solution formulation of the acid station, reduce the input of $\mathrm{CS}_{2}$ and $\mathrm{ZnSO}_{4}$ or find their alternative chemicals.

In this study, water scarcity footprint of the pulping with the value of $28.815 \mathrm{~m}^{3} \mathrm{H}_{2} \mathrm{O}$ eq/ton were the largest in the viscose textile production, this means that massive amount of water was consumed in the pulping process. The viscose fiber production department can improve the presoaking process, reduce the input of fresh water and alkali, or increase the recovery rate of black liquor. Moreover, this paper calculated the average water scarcity footprint in China, the water scarcity footprint would be even large if the pulping process occurred in water-deficient area. Furthermore, the calculation results of the water degradation footprint did not take into account the differences in the water environment of each region, such as the natural background concentration. The same pollutants are discharged into clean water bodies and heavily polluted water bodies, and the load on the two water bodies will be definitely different. The LCA polygon analyses showed comprehensive evaluation of water resources environmental load in viscose textile production. Significantly, the units of water scarcity footprint and water ecotoxicity footprint are $\mathrm{m}^{3} \mathrm{H}_{2} \mathrm{O}$ equivalent, while the units of water eutrophication footprint, water acidification footprint, and water alkaline footprint are kg reference pollutant equivalent. It may be controversial to put the indicators with different unit categories on the same plane for comprehensive evaluation, but the final results did roughly reflect the overall environmental load. In future research, attempts should be made to convert the water footprint results to the same equivalent, so that the comprehensive environmental impact expressed by the LCA polygon area will be more accurate.

\section{ACKNOWLEDGEMENTS}

This research was funded by the National Key R\&D Program of China (Project No.2018YFF0215703), the Natural Science Foundation of Zhejiang Provincial (Project No.LY20G030001), the Young Researchers Foundation of Zhejiang Provincial Key Laboratory of Fiber Materials and Production Technology, Zhejiang Sci-Tech University (Project No.2016QN06), the National Natural Science Foundation of China (grant number 61702460), the Researcher Foundation of Zhejiang Provincial Research Center of Clothing Engineering Technology (2018FZKF10).

\section{REFERENCES}

[1] Dang, W.Q., How culture shapes environmental public participation: case studies of China, the Netherlands, and Italy, In: Journal of Chinese Government. 2018, 3, 2, 1-23

[2] Ma, X.T., Ye, L.P., Qi, C.C., Yang, D.L., Shen, X.X., Hong, J.L., Life cycle assessment and water footprint evaluation of crude steel production: A case study in China, In: Journal of Environmental Management, 2018, 224, 10-18

[3] Wang, L.L., Ding, X.M., Wu, X.Y., Blue and grey water footprint of textile industry in China, In: Water Science \& Technology, 2013, 68, 11, 2485-2491

[4] Yavas, A., Color and fastness properties of printed with reactive dye viscose fabrics and fixed with radio frequency energy, In: Industria textilă, 2013, 64, 2, 98-105

[5] Ma, D.C., Xian, C.F., Zhang, J., Zhang, R.C., Ouyang, Z.Y., The Evaluation of Water Footprints and Sustainable Water Utilization in Beijing, In: Sustainability, 2015, 7, 13206-13221

[6] Hoekstra, A.Y., Chapagain, A.K., Aldaya, M.M., Mekonnen, M.M., The Water Footprint Assessment Manual: Setting the Global Standard, Earthscan: London, UK, 2011

[7] Hoekatra, A.Y., Chapagain, A.K., Zhang, G.P., Water Footprints and Sustainable Water Allocation, In: Sustainability, 2016, 8, 20

[8] Wang, L.L., Ding, X.M., Wu X.Y., Ndwiga, D.-K., The introduction of water footprint methodology into the textile industry, In: Industria textilă, 2014, 65, 1, 33-36

[9] International Standard Organization (ISO), Environmental Management-Water Footprint-Principles, Requirements and Guidelines. International Organization for Standardization: Geneva, Switzerland, 2014

[10] Bai, X., Ren, X.J., Khanna, N.Z., Zhou, N., Hu, M.T., Comprehensive water footprint assessment of the dairy industry chain based on ISO 14046: A case study in China, In: Resources, Conservation \& Recycling, 2018, 132, 369-375

[11] Zonderland-Thomassen, M.A., Ledgard, L.S.F., Water footprinting-A comparison of methods using New Zealand dairy farming as a case study, In: Agricultural Systems, 2012, 110, 5, 30-40

[12] Zonderland-Thomassen, M.A., Ledgard, L.S.F., Water footprint of beef cattle and sheep produced in New Zealand: water scarcity and eutrophication impacts, In: Journal of Cleaner Production, 2014, 73, 12, 253-262

[13] Bai, X., Hu, M., Zhu, C., Ren, X., Bao, W., Sun, L., Evaluation of the water footprint of industrial products based on ISO 14046 using cables as an example, In: Acta Ecologica Sinica, 2016, 36, 7260-7266 
[14] Naranjo-Merino, C.A., Ortíz-Rodriguez, O.O., Villamizar-G, R.A., Assessing Green and Blue Water Footprints in the Supply Chain of Cocoa Production: A Case Study in the Northeast of Colombia, In: Sustainability, 2018, 10, 38

[15] He, W.W., Li, Y., Wang, L.L., Calculation and assessment of product water footprint of textiles and apparel based on ISO 14046, In: Dyeing, 2017, 43, 17, 52-55

[16] He, W.W., Li, Y., Wang, X.P., Wang, L.L., Calculation and assessment of benchmark water footprint of silk products, In: Advanced Textile Technology, 2018, 26, 2, 41-45

[17] Heijungs, R., Guinee, J.B., Huppes, G., Lankreijer, R.M., Udo de Haes, H.A., Wegener Sleeswijk, A., Environmental Life Cycle Assessment of Products, Centre of Environmental Science: Leiden, Netherlands, 1992

[18] Kounina, A., Margni, M., Bayart, J.-B., Boulay, A-M., Berger, M., Bulle, C., Frischknecht, R., Koehler, A., Milà i Canals, L., Motoshita, M., Núñez, M., Peters, G., Pfister, S., Ridoutt, B., Rosalie van Zelm, Verones, F., Humbert, S., Review of methods addressing freshwater use in life cycle inventory and impact assessment, In: The International Journal of Life Cycle Assessment, 2013, 18, 707-721

[19] Huang, J., Ridoutt B.G., Zhang, H., Water Footprint of Cereals and Vegetables for the Beijing Market, In: Journal of Industrial Ecology, 2014, 18, 1, 40-48

[20] Linhares, T., Pessoa de Amorim, M.T., LCA of textile dyeing with Acacia Dealbata tree bark: a case study research, In: Procedia Engineering, 2017, 200, 365-369

[21] Daniel, S.E., Tsoulfas, G.T., Pappis, C.P., Rachaniotis, N.P., Aggregating and evaluating the results of different Environmental Impact Assessment methods, In: Ecological Indicators, 2004, 4, 125-138

[22] Georgakellos, D.A., The use of the LCA polygon framework in waste management, In: Management of Environmental Quality, 2006, 17, 4, 490-507

[23] Georgakellos, D.A., Evaluation of life cycle inventory results using critical volume aggregation and polygon-based interpretation, 2005, 13, 6, 567-582

[24] Lovarelli, D., Ingrao, C., Fiala, M., et al., Beyond the Water Footprint: A new framework proposal to assess freshwater environmental impact and consumption, In: Journal of Cleaner Production, 2018, 172, 4189-4199

[25] Xiao, C.F., Introduction to Chemical Fibers, 3rd ed., China Textile \& Apparel Press: Beijing, China, 2015

[26] Wu, J.H., Dyeing and finishing of cellulose fiber fabric, China Textile \& Apparel Press: Beijing, China, 2015

[27] Zhang, L.S., Printing and dyeing wastewater treatment technology and typical engineering, Chemical Industry Press: Beijing, China, 2005

[28] Pfister, S., Koehler, A., Hellweg, S., Assessing the environmental impacts of freshwater consumption in LCA, In: Environmental Science \& Technology, 2009, 43, 4098-4104

[29] Varela Diaz, V.M., Guarnera, E.A., Coltorti, E.A., Life-cycle impact assessment: A conceptual framework, key issues, and summary of existing methods, United States, 1995

[30] Yan, Y., Jia, X.X., Shan, P., Wu, G., Water environmental impact assessment of urban development based on water degradation footprint: a case study of Beijing, In: Acta Scientiae Circumstantiae, 2017, 37, 2, 779-785

[31] Boulay, A.M., Bare, J., De Camillis, C., Consensus building on the development of a stress-based indicator for LCA-based impact assessment of water consumption: outcome of the expert workshops, In: The International Journal of Life Cycle Assessment, 2015, 20, 5, 577-583

[32] Moga, I.C., Matache, M.G., Covaliu, I.C., Advanced wastewater treatment stage for textile industry, In: Industria Textila, 2018, 69, 6, 478-482, http://doi.org/10.35530/lT.069.06.1501

[33] Moga, I.C., Ardelean, I., Petrescu, G., Crăciun, N., Popa, R., The potential of biofilms from moving bed bioreactors to increase the efficiency of textile industry wastewater treatment, In: Industria Textila, 2018, 69, 5, 412-418, http://doi.org/10.35530/IT.069.05.1500

[34] Qamar, M.T., Mumtaz, H.M., Mohsin M., Asghar, H.N., Iqbal, M., Nasir, M., Development of floating treatment wetlands with plant-bacteria partnership to clean textile bleaching effluent, In: Industria Textila, 2019, 70, 6, 502-511, http://doi.org/10.35530/IT.070.06.1679

\section{Authors:}

\section{JUXIANG ZHU, YIDUO YANG, YI LI, PINGHUA XU, LAILI WANG}

Engineering Research Center of Clothing of Zhejiang Province, Hangzhou, Zhejiang 310018, China School of Fashion Design \& Engineering, Zhejiang Sci-Tech University, Hangzhou, Zhejiang 310018, China Silk and Fashion Culture Research Center of Zhejiang Province, Zhejiang Sci-Tech University, Hangzhou, Zhejiang 310018, China

e-mail: m18020197360@163.com (Z. J.); 1362405534@qq.com (Y. Y.); liyi2009@zstu.edu.cn (L.Y.); shutexph@163.com (X.P.)

Corresponding author:

LAILI WANG

e-mail: wangll@zstu.edu.cn 